UDC 811.111

DOI https://doi.org/10.32841/2409-1154.2021.51-3.12

Manhura S. I.,

Lecturer, Department of Germanic Philology and Translation National University "Yuri Kondratyk Poltava Polytechnic"

\author{
Palii K. V., \\ Ph.D., Senior Lecturer, Department of Germanic Philology and Translation \\ National University "Yuri Kondratyk Poltava Polytechnic"
}

\author{
Astakhova S. A., \\ Senior Lecturer, Department of Germanic Philology and Translation \\ National University "Yuri Kondratyk Poltava Polytechnic"
}

\title{
THEORETICAL ASPECT OF TRANSLATION OF ENGLISH AND GERMAN NEWSPAPER HEADLINES
}

Summary. The article is devoted to the problem of translating the headlines of English and German newspapers and magazines into Ukrainian. Headlines in German and English newspapers play an important role. Their main purpose is to attract readers' attention, arouse interest and even excite. Information and explanatory functions, which are the subject of the whole article, are only its secondary purpose. For example, English language is characterized by a refusal to use phraseology, idioms, puns, as well as a complex grammatical structure that causes serious problems in translation. The article presents an analysis of the fundamental aspects of the translation of headlines, identifies their structural-grammatical and lexical functions.

Adequate translation is intended, first of all all, the transfer of the substantive side of the original, which can dictate a change in the formal structure without violating the rules of the language of translation. In order to achieve adequate translation of media headlines, it is necessary to apply translation transformations. Interlingua transformations are the transformation of a text in one language into an equivalent text in another language.

Characteristic features of newspaper headlines are the compression of language units of all levels, the use of polysemous words, quotations, phrases, idioms, puns, etc. Media headlines implement compression of the form and expressiveness of the content. This translation is a great game with the reader to convince and entertain him/her, which perfectly meets the challenges of mass communication styles.

Certain difficulties in understanding newspaper headlines may be associated, first of all, with the violation of language norms, and secondly, in the absence of deep knowledge of national reality and culture and with the irrelevant translation of phraseology. It is noted that to perform relevant adequate translation it is important to understand the information, content, communicative function and stylistic effect of specific features of the text.

It is also necessary to distinguish between metaphors, allusions, irony, puns and other stylistic devices and gain in-depth knowledge of the reality to which the text is devoted.

Key words: translation, newspaper, headline, linguistic level, background knowledge.

Formulation of the problem. The purpose of our research is to analyze the features of English and German news media head- lines, their main functions based on a critical analysis of existing approaches to the study of this issue, as well as to identify translation features in connection with lexical-morphological, syntactic and stylistic features of headlines.

The article is devoted to the issue of translating headlines of English newspapers and journals into Ukrainian. Headlines in English and German newspapers play an important role. Their prior purpose is to attract readers' attention, to arouse interest and even provoke excitement. An informative and explanatory function, that is presenting the subject of the whole article, is only its secondary purpose.

English and German press, as well as the Ukrainian press, formed its own style of newspaper headline with its own linguistic features. Therefore, there may be difficulties in translating the headlines. The change in the rules for constructing headlines in both languages leads to some changes in the ways of translating newspaper headlines into Ukrainian. Translation of the headline that has number specific features, can be considered a separate translation problem. For example, English language is characterized by abandoning use of phraseological units, idioms, puns as well as a complicated grammatical structure which cause some serious problems while translating.

Stylistic features of foreign and Ukrainian headlines are almost indistinguishable. All newspaper headlines are characterized by general forms of realization of brevity, compression of information. As a result of brevity there is a saving of language means due to communicatively less important fragments of the message. The main stylistic principle of organizing the language of headlines in journalism is a combination of standard and expression.

The article presents an analysis of fundamental aspects of translation of newspaper headlines, defines their structural-grammatical and lexical features, and suggests translations of some headlines on the actual material of English and German newspaper articles.

The purpose of this paper is to highlight some aspects of translating English and German newspaper headlines, to claim the importance to preserve the intelligible and coherent character of information and to use equivalent language means while translating. The special style of the headlines of newspaper articles can cause some difficulties in translation. That is why in this paper the attention is mainly paid to the peculiarities of English-language newspa- 
per headlines, it also studies and compares the types of headlines of the English, German and Ukrainian press, there are some differences between them. Characteristic features of newspaper headlines are compression of language units of all the levels, use of polysemantic words, quotations, phraseological units, idioms, puns, etc.

Headlines of media texts implement a compression of the form and expressive capacity of the content. Such a translation is a fine game with the reader to convince and entertain him/her which perfectly meets the challenges of the mass communication styles. Certain difficulties in understanding of newspaper headlines can be connected, first of all, with violation of language norms, secondly, with lack of profound knowledge of the national reality and culture and with irrelevant translation of phraseological units. It is distinguished that to perform a relevant adequate translation it is important to understand the essential information, the content, the communicative function and stylistic effect of the specific features of the text.

It is also necessary to distinguish metaphors, allusions, irony, puns and other stylistic devices and obtain profound knowledge about the reality the text is devoted to.

Current trends in the development of newspaper headlines can be traced in the strengthening of their communicative and meaningful function, in increasing the author's irony. Headlines are increasingly advocating for meaning and have a strong emotional impact on the reader. Lexical and stylistic means allow making the headline brighter and help to convey the hidden meaning, to reveal the author's position. A good headline greatly enhances competitiveness of the periodical.

The headlines of the print media perform the following functions:

Advertising. This is one of the most important ways to draw attention to what the reader, according to the editors, cannot miss.

Motivational. The headline should contain enough information so that the reader can decide whether he needs to continue communicating with the text.

Information. Even if a person is limited to reading only the headline, he must get the set of facts needed to form a picture of what is happening, or get an idea of the essence of the story. Translation is the basic form of international intercourse, providing mankind with possibility of information exchanging as well as scientific, technical and cultural heritage mutual exchange. And nothing else but literary translation/ interpretation provides acquainting both scholars and average people with the newest world literature achievements. Translation possesses its special role in the literary process. Every kind of literature has got the certain type of translation to be used/ usable. As for the headlines, interpreters prefer to employ literary translation. It is certainly one of the most expressive manifestation of trans-literary interaction, which includes, of course, transcultural interaction as well.

Extensive exchange of information between the peoples of the world requires constant translation of information messages and journalistic articles published in the print and electronic media. According to many translators, written translation of journalistic texts is one of the main types of translation [1]. When performing a written translation, the translator has the full opportunity to carefully select such equivalents for all elements of the original text, which will ensure the comprehensive adequacy of the translation of the original, i.e. create in its entirety such a secondary text that will have a content that fully corresponds to the communicative task.
An important role in the perception of any text is played by its component such as the headline. This is most clearly seen in the material of newspaper articles, which appear in concentration on the pages of modern printed and electronic publications, thus creating certain alliance of interrelated competing texts. The modern reader does not read all the texts, as it probably was before in the twentieth century, and gets acquainted primarily with their headlines. After all, with the increase in the ability to obtain information, primarily through the Internet, the latest multimedia tools, the attention of potential readers is focused mainly on visually distinguishing accurate headlines.

Written translation has these advantages primarily because it is usually time-limited and allows the translator to access a variety of dictionaries and reference books without overloading their RAM. However, the use of dictionaries and reference books in the process of translation practice must be very careful, except as the translation is not individual words, but their meaning in the general context, which corresponds to the communicative task, which is determined not only by the purpose of the communicative act. Dictionaries usually do not take into account these factors and describe the meaning of words in the most commonly used contexts. Proper use of the dictionary should help the translator to find the right solution in each case [2].

Analysis of recent research. We will focus on the only one aspect of the correct reproduction of the communicative task in the translation. It will be about the adequacy of the translation of the headline and the prevention of literalism. In our opinion, this topic is insufficiently developed in Ukrainian translation studies. In any case, we have found little work on the translation of the news headline and adequate reproduction of the communicative task in it. Based on the above, we chose the research topic. The main criterion for the selection of materials used in the work was their saturation with linguistic phenomena, most characteristic of the newspaper and journalistic style.

After analyzing the classifications of different authors, we can conclude that linguists do not have a single view on the ways of transformation of phraseological units. Classifications differ significantly from each other. No classification is exhaustive. This indicates a lack of study of the transformation of phraseology in linguistics. In fact, we are interested in the question of possible correspondence between English, German language and Ukrainian, in which the translation retains the ability to convey the content of the original work, as well as its dominant purpose, which to some extent depends on the accuracy of the translation. As a result of our research, we found that approximately $40 \%$ of full words (nouns, adjectives, verbs, adverbs) from journalism are translated into the main European languages (among them ours, Ukrainian) with unambiguous equivalents.

In this case, we have a complete correspondence between the units of the two languages, as there is a complete correspondence between the concepts. The translation of such units does not require reference to reality and can be carried out in accordance with the law. Actually, this translation is called literal.

Presentation of the main material and substantiation of research results. A study of translations of publications from English and German media made by Ukrainian newspapers shows that translators transfer to the language of translation (Ukrainian) the meaning of the element of the original language, i.e. seems to expand the general (common) part of the concepts of English, Ger- 
man and Ukrainian. This is usually accompanied by some disorders norms of the Ukrainian language and is perceived as literalism [3]. In other words, the information content of the text, which is called the plan of content, remains in the language of the original, and the form of expression of this content (plan of expression) is transferred to the language of translation, where it is perceived as a foreign phenomenon. The content in this case is perceived at the level of invariance, and the form - as literalism [4]. The dialectical unity of form and content is violated.

The newspaper is designed for a massive and heterogeneous audience, which must somehow be attracted. As a rule, the newspaper is read in such conditions when it is difficult for a person to concentrate: at breakfast, in transport, during a lunch break or after work. Therefore, it is necessary to transfer information quickly, concisely, to inform the main thing and to "entice" the reader. Newspaper headline as a specific linguistic phenomenon is the subject of many scientific papers. As an object of study, the English headline very often attracts attention. The translation of the headline can be considered a separate problem of translation studies.

However, in the process of finding an adequate translation, even experienced translators sometimes resort to literalism, in order to better understand the meaning of the original and on the basis of understandable to find an adequate expression. This technique allows the translator to find out all the differential features that characterize this concept, and this allows you to then find in the language of translation adequate correspondence, including the necessary differential feature.

In the Ukrainian language (in contrast to the German), the forms of the possessive (mine, yours, his) and the inverse possessive pronoun (own) are opposed. Both pronouns express the relation of belonging to the subject of action, as this meaning is peculiar only to the inverse pronoun. The personal possessive pronoun does not matter the subject matter of the subject (I give your book and you give my book). While the inverse possessive pronoun "my" means the belonging of the subject to the subject (I take my notebook, you take yours). There is no need to reflect the identity and numbers of owners, as the characteristics are always given in the subject.

There may be difficulties in understanding newspaper headlines related, first of all, to violations of language norms; secondly, with insufficient knowledge of the realities and culture of the country, as well as phraseology. There are no ready-made recipes and universal methods for translating newspaper headlines [5].

The main rule of the translator in such cases is to translate them on the basis of information, context and the full text of the article, taking into account the methods of psychological action based on stereotypes audience. If the translator is ready in advance for such problems, if he is aware of the essence, content, communicative function and stylistic effect of the features of the text, with the ability to recognize metaphors, allusions, irony, puns, etc., having the necessary knowledge and ideas about the reality to which the text is devoted, it is hoped that its translation will be enough adequate [6].

Conclusions. The headline in newspapers plays important role. His primary task is to attract the reader's attention, the desire to interest and even impress him and only in the second place the headline is given an informational and explanatory function - to inform the reader of the summary of the article. Communicative translation is suggested to handle the translation of news headlines featuring unique characteristics on the lexical and grammatical levels.
Thus, the headlines of media texts are a compression of form and have a clear capacity for content. Their translation is a subtle game with a reader who needs to be convinced and captivated, which corresponds to the tasks of the style of mass communication.

A fresh and appropriate rhetoric device will more often than not make the statement lively, impressive and interesting. Since translators must ensure the faithful information transmission, on the one hand, and also reserve the rhetorical features of headlines, on the other hand, translators should use communicative and semantic translation alternately in dealing with the translation of headlines characterized by rhetoric devices.

In news headlines translation, communicative translation could retain the original denotation of the headline while explaining the connotation that target language readers need to know. Before dealing with the rhetoric devices, translators should do some preliminary work such as searching for the background knowledge about the report, the journalist's viewpoint about the event. Based upon the preliminary work, translators can then accurately figure out the connotation of the devices and then try to find equivalent to reproduce the effect obtained by original readers.

Written at the author's linguistic level, semantic translation can help recreate the precise flavor and tone of the original text.

The headline of media texts is a well-studied linguistic phenomenon, but it requires further scientific research in the field of translation studies, as the subject of research is not permanent and undergoes daily influence and transformation.

\section{References:}

1. Багмут Й. Проблеми перекладу суспільно-політичної літератури українською мовою : навчальний посібник. / за заг. ред. Й. Багмут. Київ, 2018. 275с

2. Коптілов І.В. Теорія і практика перекладу : навчальний посібник. / за заг. ред. І.В. Коптілов. Київ, 2013. 280 с.

3. Рильський М. Мистецтво перекладу : навчальний посібник. / за заг. ред. М. Рильський. Київ, 2015. 90 с.

4. Алексеева И.А. Введение в переводоведение : учебное пособие./ под общ. редакц. И.А. Алексеева. Санкт-Петербург, 2004. 352 с.

5. Збіглей І., Мусурівська О. Стилістичні особливості заголовків у публіцістичному стилі. Науковий вісник Чернівецького університету. Серія «Германська філологія». 2015. № 751. С. 79-86.

6. Карабан В.І. Переклад англійської наукової і технічної літератури. Граматичні труднощі, лексичні, термінологічні та жанрово-стилістичні проблеми : навчальний посібник. / за заг. ред. В.І. Карабан. Вінниця, 2004. 564 c.

Мангура С., Палій К., Астахова С. Теоретичний аспект перекладу англійських та німецьких газетних заголовків

Анотація. Стаття присвячена проблемі перекладу заголовків англійських та німецьких газет та журналів українською. Заголовки в німецьких та британських газетах відіграють важливу роль. Їхня основна мета - привернути увагу читачів, викликати інтерес і навіть викликати азарт.

Інформаційно-пояснювальні функції, що становлять предмет усієї статті, є лише другорядним іiі призначенням. Так, наприклад, англійська мова характеризується відмовою від використання фразеологізмів, ідіом, каламбурів, а також складних граматичних структур, що викликає серйозні проблеми під час перекладу. У статті подано аналіз фундаментальних аспектів перекладу заголовків, визначено їх структурно-граматичні та лексичні функції. 
Характерні риси газетних заголовків - це стиснення мовних одиниць усіх рівнів, використання багатозначних слів, цитат, фразеологізмів, ідіом, каламбурів та ін. Заголовки медіатекстів реалізують стиснення форми та виразності змісту. Такий переклад - чудова гра $з$ читачем, щоб переконати і розважити його/іiі, що ідеально відповідає викликам стилів масового спілкування.

Певні труднощі у розумінні газетних заголовків можуть бути пов'язані, по-перше, із порушенням мовних норм, по-друге, з відсутністю глибоких знань національної дійсності та культури та 3 неактуальним перекладом фразеологізмів. Зазначено, що для виконання актуального адекватного перекладу важливо розуміти інформацію, зміст, комунікативну функцію та стилістичний ефект специфічних особливостей тексту.
Також необхідно розрізняти метафори, алюзії, іронію, каламбури та інші стилістичні прийоми та отримати глибокі знання про реальність, якій присвячений текст. Особливий стиль заголовків газетних статей може спричинити певні складнощі під час перекладу. У перекладі заголовків новин комунікативний переклад зберігає оригінальне значення заголовка, водночас пояснюючи конотацію, яку мають знати читачі, цільовою мовою.

Заголовок медіатекстів $є$ добре вивченим лінгвістичним явищем, але потребує подальших наукових досліджень у сфері перекладознавства, оскільки предмет дослідження не $є$ постійним і зазнає щоденного впливу та трансформації.

Ключові слова: переклад, газета, заголовок, лінгвістичний рівень, фонові знання. 